\title{
PSYCHE.
}

\section{ON THE OCCURRENCE OF DISSOSTEIRA LONGIPENNIS THOMAS.}

\author{
BY S. J. HUNTER.
}

Department of Entomology, University of Kansas, Lawrence.

Professor L. Bruner, in his report to the Nebraska State Board of Agriculture for 1896 , says that though Dissosteira longipennis has been known to entomologists for twenty-five years, it has been classed among our rarer Acrididae until $\mathrm{r} 89 \mathrm{r}$. At this time he was called upon to investigate its habits in eastern Colorado, where it had appeared in large numbers. He afterwards speaks of its habitat, and here we quote his language.* "It is rather restricted in its normal range, being found only upon the plains of western Nebraska, Kansas, southeastern Wyoming, eastern Colorado, and northeastern New Mexico, at an elevation of from 3,500 to 6,000 feet above sea level. It is also known to occur, for the most part, upon the gravelly slopes where vegetation is quite sparse." Continuing his report to the State Board of Agriculture, he states that the insect has found its way eastward almost to the Missouri river in Kansas and Nebraska.

* Report to Riley, under whose instructions investigations were made. Builetin No. 28, Div. Ent. U. S. Dept. Agric., pp. $3 \mathrm{t}-39$.
In the field work of this department during the past summer, the writer had occasion to give special attention to grasshoppers. Dissosteira longipennis was occasionally seen in the territory under observation, being in all thirteen counties situated between the 99th meridian and the west line of the State. In Edwards county, six miles south of Offerlie, however, this locust was abundant in a portion of an alfalfa field of 320 acres. In bare spots, where no. alfalfa grew, more than a dozen insects would take wing when disturbed and fly in different directions for a short distance. This was observed first on July 6th. On September ist females of this species were seen ovipositing in this field. It is the writer's opinion that this colony was bred and reared upon this ground.

In the latter part of September, 1897 , the writer captured a single female three miles south of Lawrence in a closely grazed pasture. In August, r 898 , a student of this department took two females upon the university campus. On September $24^{\text {th }}$ of this year the 
writer found another specimen six miles west of Lawrence in a strawberry patch on a high hill overlooking Lake View.

In a letter upon this subject, Mr. S. $\mathrm{H}$. Scudder gives references to the capture of Dissosteira longipennis, in Texas (Boll), in Nebraska, "entire state" (Bruner), in extreme western Kansas (Osborn), Barber Co., Kansas (Bruner). He says farther: "I have 34 refer- ences to it in literature, but in none do I find a reference to its capture as far east as Lawrence," and thinks it improbable that it has been reported as taken this far east.

These notes are given in evidence of what may be considered an eastward tendency in the geographical range of this insect.

\title{
NOTES ON NEW ENGLAND ACRIDIIDAE, IV, - ACRIDIINAE. - V.
}

\author{
BY ALBERT P. MORSE, WELLESLEY, MASS.
}

4I. Melanoplus extremus Walk.

Figs. 4I, a.

Caloptenus extremus. Walker, Cat. Dermapt. Salt. Brit. Mus., IV, 68I, (1870).; Thomas, Syn. Acrid., 225.

Melanoplus junius. Morse, List, 106. " extremus. Scudder, Rev. Melanopli, 287 , pl. xviii, fig. 10.

Measurements from $62 \delta, 82$ o:Antenna: $\delta, 7.5-9 ;$ \& , 6-8. H. fem.: ठ, 9.4-г1.2; $\uparrow$, го-12.6. Teg. : $\delta$, 9.5-16; क, 10-18. Body: ठै, 15-19; \&, 15.5-24. Total: $\delta, 15^{-22} ;$ \&, I6-24. Teg. $v s$. H. fem. : $\delta,-3$ to +3 ; \&, -4 to +3 .

A very variable species. In the fresh state its general coloring - a peculiar olive with blackish markings - is very appreciable and of service in recognizing it, though the long-winged female is liable to be mistaken for femur-ru- brum. While tegmina of every length between the extremes given are to be found, most of the specimens observed fall into two series, a short- and a longwinged. In the former the tegmina usually fall about $2 \mathrm{~mm}$. short of the end of the hind femora; in the latter pass them by 2 or $3 \mathrm{~mm}$.; - the names junius and scandens respectively have been applied to these by Scudder. Of the specimens now in my collection (a number having been disposed of through exchanges) about one-eighth of the females and two-thirds of the males are long-winged (scandens). The longwinged form seems to be more prevalent in high latitudes and at high elevations. In point of size also the species varies much according to locality, specimens from Winchendon, Mass., $(800-1200 \mathrm{ft}$.) being noticeably larger than those from the summit of Mt. 

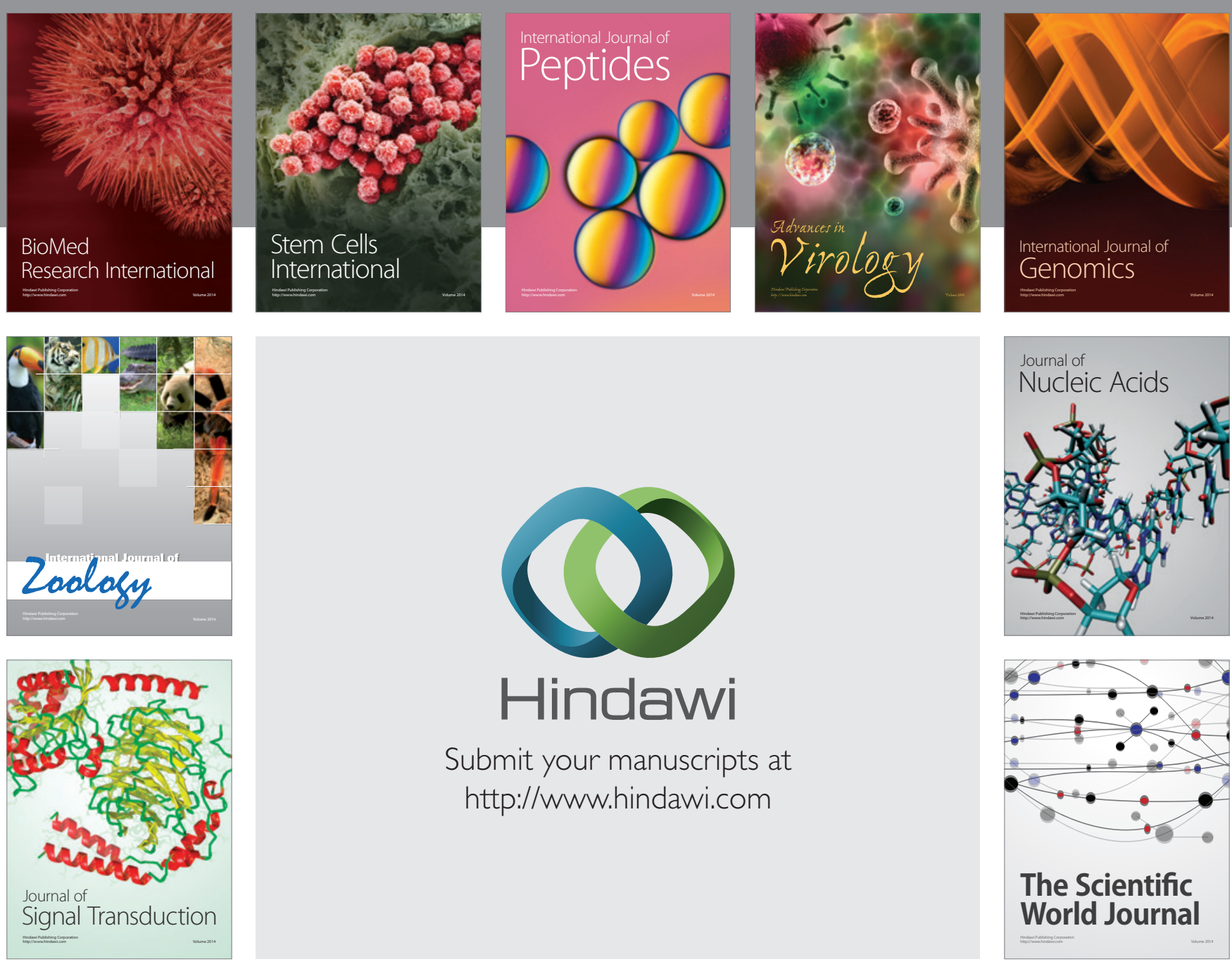

Submit your manuscripts at

http://www.hindawi.com
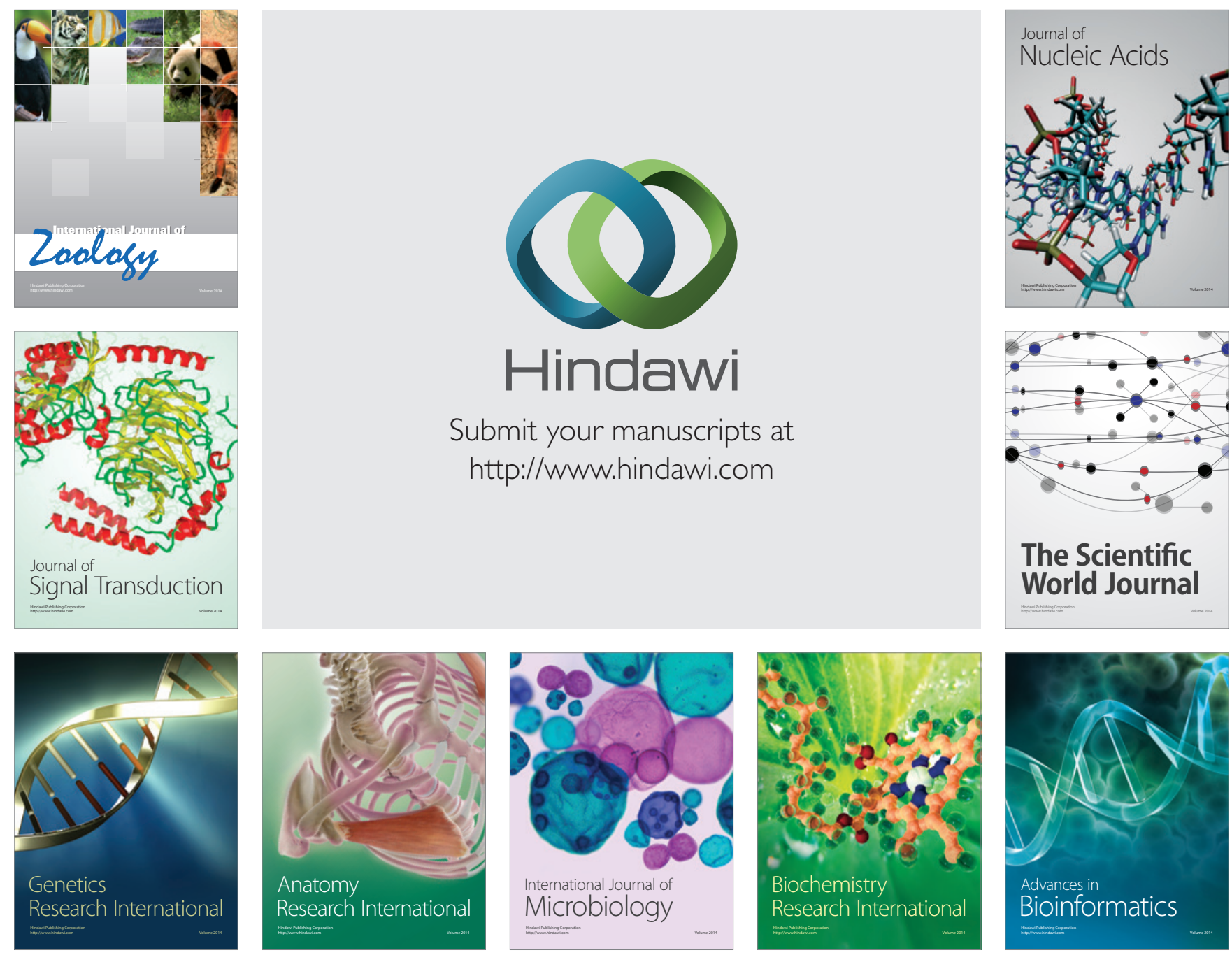

The Scientific World Journal
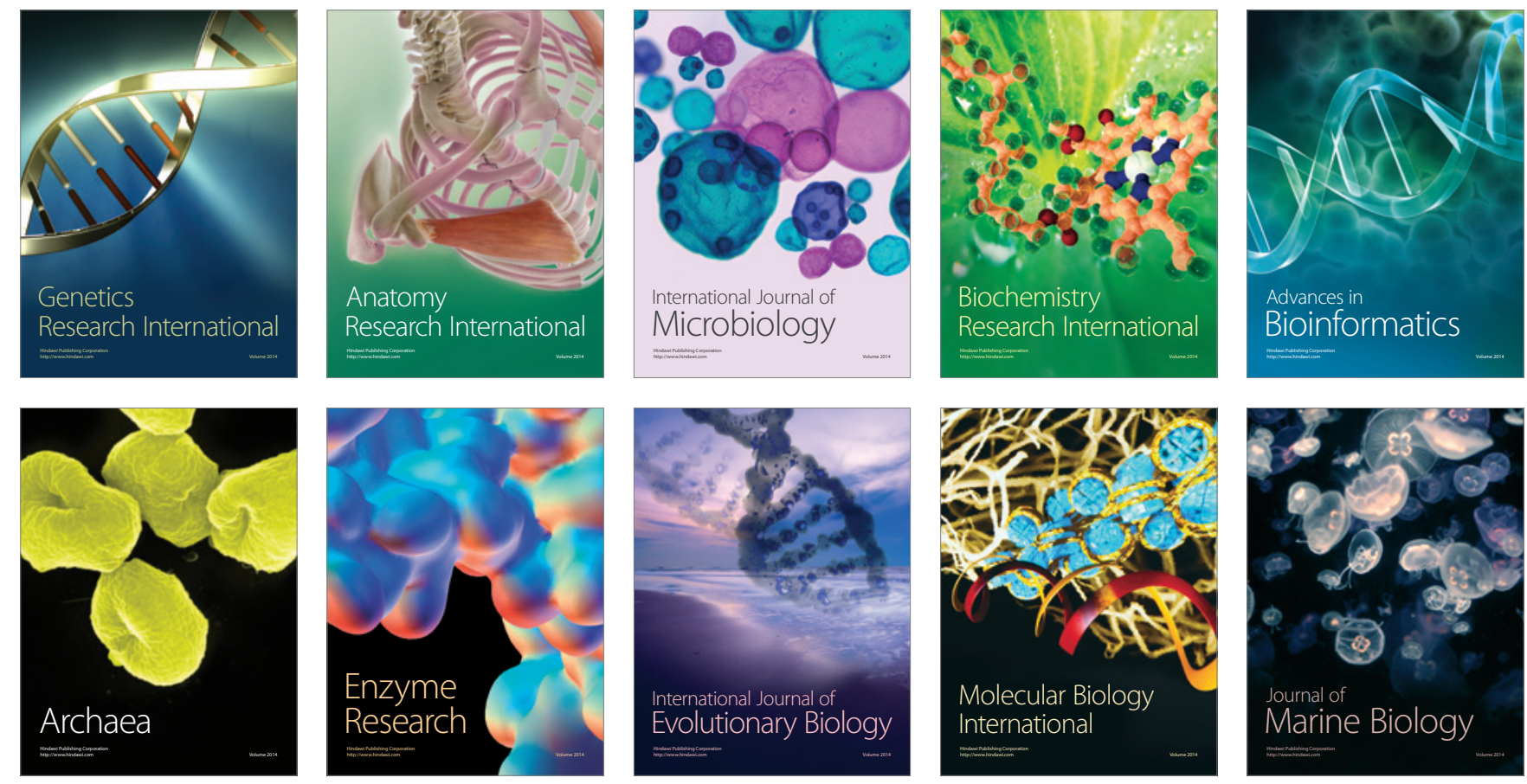